\title{
極微小デバイスを用いた生体分子・細胞・組織の顕微操作と解析
}

\author{
新田英之 ${ }^{1,2}$, 東山哲也 ${ }^{1,2,3}$ \\ ${ }^{1}$ JST, ERATO 東山ライブホロニクスプロジェクト $=464-8602$ 名古屋市千種区不老町 \\ 2 名古屋大学 理学研究科 生命理学研究科 $\bar{T} 464-8602$ 名古屋市千種区不老町 \\ ${ }^{3}$ 名古屋大学トランスフォーマティブ生命分子研究所 †464-8602 名古屋市千種区不老町
}

要旨 : 近年顕微鏡技術の発達により，生きたままの組織や細胞内を観察するライブイメージングが可能となった。一方で，観察 対象を自由自在に操作することを目的としたハンドリング技術には多くの課題が残されていた. MEMS (Micro-Electro-MechanicalSystems）に代表される微細加工技術では，組織や細胞と同じサブミクロンスケールの微小な実験システムをカスタムメイドで製作す ることが可能である．本総説では，微細加工を施したマイクロチップを，酵素やモータ蛋白質など生体分子観察・操作に応用した 例と，根や花粉管などの植物試料分析に応用した最新の研究を紹介する．最後に，従来のバルク計測系に比べての利点，一分 子計測技術によるナノスケール操作や光造形技術によるミリスケール加工との併用を含めた今後の可能性について述べる.

\section{Micromanipulation and analysis of biomolecules, cells, and tissues using microfabricated devices}

\author{
Hideyuki Arata ${ }^{1,2}$, Tetsuya Higashiyama ${ }^{1,2,3}$ \\ ${ }^{1}$ JST, ERATO, Higashiyama Live-Holonics Project, Nagoya University, Furo-cho, Chikusa-ku, Nagoya, Aichi 464-8602, Japan \\ ${ }^{2}$ Graduate School of Science, Nagoya University, Furo-cho, Chikusa-ku, Nagoya, Aichi 464-8602, Japan \\ ${ }^{3}$ Institute of Transformative Bio-Molecules (ITbM), Nagoya University, Furo-cho, Chikusa-ku, Nagoya, Aichi 464-8602 \\ Author for correspondence: H. Arata, arata.hideyuki@i.mbox.nagoya-u.ac.jp
}

\begin{abstract}
Summary: Live imaging inside the living tissues and cells has become possible, in recent years, owing to the advancement of microscopic technologies. On the other hand, techniques to handle and manipulate samples during live imaging have many issues to be overcome. Microfabrication technologies represented by MEMS (Micro-Electro-Mechanical-Systems) allow us to produce custommade miniaturized experimental systems at the micrometer to sub-micrometer scale, which is as same scale as tissues or cells. This review introduces studies of observation and manipulation of enzymes, motor proteins, roots and pollen tubes using microfabricated systems to show the merits on applying those technologies to biological assays. Finally, the review discusses advantages of microsystem-based bioexperiments in general and future prospects of combination with single molecule nano-manipulation technique and stereolithographic technology at the millimeter scale.
\end{abstract}

Key words: Pollen tube, Root, Biomolecule, MEMS, MicroTAS

\section{はじめに}

生命科学におけるブレークスルーは，しばしば新しい観察・ 計測技術の発明や発展によりもたらされてきた。 16 世紀末に 発明された光学顕微鏡は 17 世紀には細胞の発見を初め, 生 物学, 医学, 物理学に革命をもたらし, 現在ではその精度 の向上と多様化により，蛍光顕微鏡によるモー夕蛋白質の機 械的挙動一分子イメージング (Noji et al. 1997, Kitamura et al. 1999）や，生きた細胞内の一分子モニタリングも可能となた (Luo et al. 2012). また，二光子顕微鏡では胚細胞内の個別 の細胞核を明確に識別することができ，生きたままの組織や細 胞内部を三次元で観察するライブイメージングの分野でも強力 なツールとなっている (Kurihara et al. 2013)。このように，観察 する「目」にあたる顕微鏡技術の進展は目覚ましいが，顕微鏡 観察下で細胞や分子を自由自在に操作・解析する「手」に相 当する技術に関しては，多くの課題が残されている．植物試 料を含む多くの生体試料の観察は，通常ガラス基板上に無作 為に配置, または固定して顕微鏡観察を行っている. そのため, 観察中試料を任意の位置，方向，角度に高精度で配向，ま
たは操作したり，外部から高い位置精度で刺激を与えその応 答を観察することは困難であった。 サブミクロンのスケールで 微細な構造物を製作できるMEMS (Micro Electro Mechanical Systems）（Trimmer 1997, Judy 2001）に代表される微細加工技 術では，細胞と同程度のスケールで「手」を製作することが可 能であり，これまで細胞，蛋白質，核酸などのハンドリングや 分析に応用されてきた (Arata et al. 2008a).

マイクロスケールにおける微細加工技術の代表ともいえる MEMS 技術は，半導体微細加工技術を応用してマイクロメー トル $\left(10^{-6} \mathrm{~m}\right)$ スケールからサブマイクロメートルスケールの構造 物を，主にシリコン基板上に製作する技術である．微小化す ることにより高感度, 高応答速度のデバイスを実現できるため, MEMS 技術は微小センサ，アクチュエータ (動力源)，微小リ アクタ，無線デバイス，光スイッチなどに応用されてきた。一 方で，主にMEMS 技術を用いて複数の化学プロセスをチップ 状で行うマイクロTAS (Micro-Total-Analysis-Systems) (Reyes et al. 2002, Auroux et al. 2002) では極微量のサンプルで化学・ 生化学分析が可能である. 微小空間で微量の液体を扱うため, 
拡散距離は短く, 比表面積(単位体積あたりの表面積)は大きく, 熱容量は小さくなる，従って，高感度，高応答速度での並列 処理や複数プロセスの連続処理などが可能である．材料費と 廃棄物量も抑えられ，これらの分析を行う需要のある生物系実 験室で「その場」分析が可能であるといら実用的なメリッ得ら れる (Arata and Fujita 2009). MEMS やマイクロTASでは，デ バイスの一括大量生産が可能であるため使い捨て実験チップ の作製が容易である。これらの技術では，小さなチップ上の 微小空間に多数の機能単位を集積することができるため，八 イスループットでスマートな分析デバイスを実現できる (Whitesides 2006, Craighead 2006). そのため, 微細加工チップは組織, 細胞, 分子に至る生体の各階層を対象とした, 多種多様な分 析実験に応用されてきた。しかし，これらの微細加工技術を 植物試料分析に応用した研究は, これまで数例報告されてい るに過ぎない.

本総説では，マイクロスケール特有の利点を生かし， MEMS やマイクロTAS なしには実現できなかった研究例として, マイクロデバイスを用いた蛋白質や核酸の分析研究を紹介し, 続いて根や花粉管細胞などの植物試料を用いた最新研究を 紹介寸る. 最後に従来の計測系と比較しての利点を論じ，一 分子計測技術との併用を含めた今後の可能性について述べる.

\section{フェムトリットルチャンバアレイを用いた酵素活性一分子計測}

シリコンゴムとも呼ばれるポリジメチルシロキサン (PDMS: poly-dimethylsiloxane）は，生体を扱うマイクロデバイスの材料 として最も広く用いられている汎用性の高いポリマーの一つで ある (McDonald et al. 2000, McDonald and Whitesides 2002). PDMS は可視光に対して透過性がよく, 生体に対してほぼ無 害であり，平坦な表面との密着性が高い。これらの特徵は, ガラス基板と密着させ，試料を閉じ込め，顕微鏡下で観察を 行うために大変有効である. 更に, PDMS は微細加工を施し た鋳型から形状を転写することが容易であるため, 多様な生 体試料実験用マイクロチップを製作することが可能である.

このPDMSを用いて，容積がフェムトリットルレベルのマイ クロチャンバアレイを製作し (Arata et al.2005)，酵素活性一 分子計測に成功した (Rondelez et al. 2005)。このマイクロチャ ンバは，酵素と基質を微小空間に閉じ込めることにより，サン プルが溶液中に拡散していくことを防ぎ，極微量の生成物で も高い液中濃度を実現できるため, 一分子あたりの生成物検 出までも可能となる. 図 1 (A) に, 微細加工を施したPDMS シート表面の走查型電子顕微鏡 (SEM: Scanning Electron Microscope）画像を示す. 鋳型となるシリコン基板は, 感光 性レジストを用いたフォトリソグラフィと反応性イオンエッチング (RIE: Reactive Ion Etching) により微細加工が施された。 この シリコン基板を鋳型として, PDMS シートに微細構造が転写さ れた. このプロセスは一つの鋳型から同一規格のPDMS シー 卜を大量に得ることができるため, 実験チップを使い捨て利用 することができる. 微細加工を施したPDMS シートとガラス基板 を密着させ，体積がフェムトリットルオーダのマイクロ格納チャ ンバを形成した. 図 1 (B) に, ホースラデイツシュ (セイヨウワサ ビ)ペルオキシダーゼ (HRP: Horse Radish Peroxydase) 酵素 と基質 (Amplex Red) をフェムトリットルチャンバに格納し, 反 応を開始してから 5 分後の顕微鏡下蛍光画像と, 各チャンバ の輝度をヒストグラムにしたグラフを示す。輝度が離散化され， チャンバに格納されているHRP酵素の数 $0,1,2,3$ に対応する
(A)

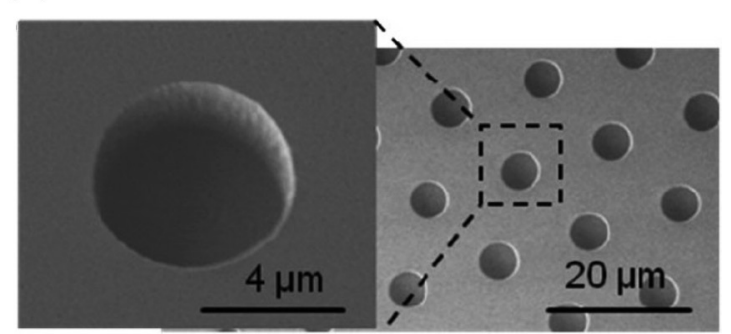

(B)

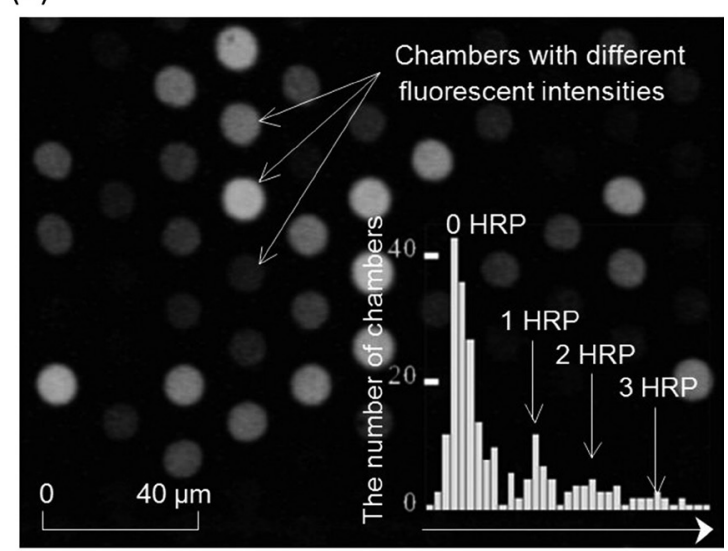

Fluorescent intensity

図 1 (A) 微細加工施されたPDMS シート表面のSEM 画像. このシー トをガラス基板とはり合わせることにより，体積 55 フェムトリットルのマ イクロチャンバが形成される. Arata and Fujita 2009, reproduced by permission of The Royal Society of Chemistry. (B)マイクロチヤンバを用 いた酵素一分子活性計測. ここでは，セイヨウワサビペルオキシダー ゼ (Horse Radish Peroxydase) によるAmplex red蛍光アッセイを示す. 酵素を $0,1,2,3$ 個格納したマイクロチャンバの蛍光輝度離散化が確認 できた. Rondelez et al. 2005から改変して転用.

ピークが見られた. 同様の実験結果が $\beta$ - ガラクトシダーゼ $(\beta$ -Galactosidase) を用いた実験でも得られた。つまり,このフェ ムトリットルチャンバを用いると, 酵素一分子レベルの極微量生 成物質を検出することができ, 酵素一分子化学活性計測が可 能である. フェムトリットルチャンバを用いるアッセイでは試料を 基板に固定する必要がないため, 分子レベルでの多種多様な 超高感度アッセイへの応用が期待できる.

\section{極微小ヒータを用いた顕微鏡下高速温度制御}

市販のサーモプレートなどを用いて，顕微鏡観察下で温度 を変化させる実験を行う場合, 解決が困難な問題が二つあった. 一つ目は, 応答速度が遅い事であり, 温度が安定するまで通 常は 10 秒から数十秒を要していた. 二つ目は, 顕微鏡ステー ジへ熱が伝わり，その熱膨張のため観察中に焦点がずれてし まう事である. これらの問題は, サーモプレートが, サンプル とそれを支えるガラス基板全体を暖めることに起因する. そこ で我々は，これらの問題を解決するため，MEMS 技術を用い て極微小温度制御デバイスを開発した (Arata et al. 2006).

図 2 (A) に，製作したマイクロ温度制御デバイスの顕微鏡写 真を示す.ガラス基板上にニッケル $(\mathrm{Ni})$ をパタニングし, 局所 領域に微小なヒータと温度センサを集積し, 直径400マイクロ メートルのマイクロ温度制御デバイスを製作した．微小なヒータ が局所空間を加熱するため, 温度上昇に必要な熱量が極め 
(A)

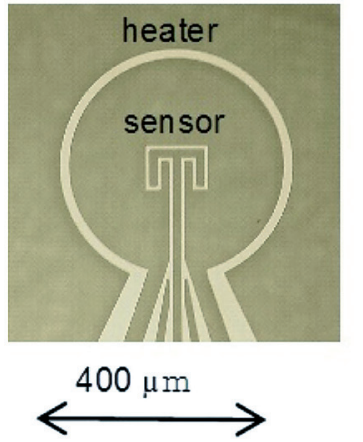

(B)

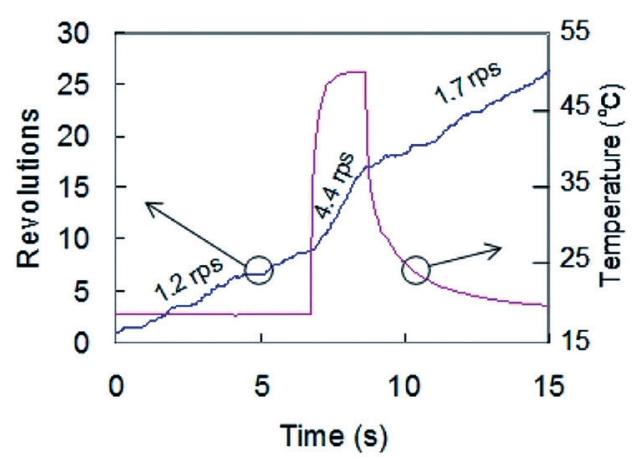

図2 (A)ガラス基板上にニッケルをパタニングし，マイ クロヒータと温度センサを集積した極微小温度制御デ バイス．（B）温度を瞬時に変化させた際の回転型モー 夕蛋白質 $\mathrm{F}_{1}-\mathrm{ATPase}$ の積算回転数時系列変化. 温度 を室温から $50^{\circ} \mathrm{C}$ へ変化させ, 室温に戻したところ, 回転速度は $1.2 \mathrm{rps}$ から $4.4 \mathrm{rps}$ 一, そして $1.7 \mathrm{rps}$ へ と変化した. Reprinted and modified with permission from Arata, Noji, and Fujita, Applied Physics Letters. Copyright 2006, American Institute of Physics.
て少ない。そのため, 高速での温度制御と, 焦点の安定とい う二つの課題を同時に克服することができる.このサイズの温 度制御デバイスでは，応答速度約 1 秒を実現した。このデバ イスで回転型モータ蛋白質 $\mathrm{F}_{1}$-ATPase $の$ 回転速度を少アルタイ ムで，かつ 1 秒の応答速度で制御することができ，高温域に おいてはトルクも上昇する $\left(10^{\circ} \mathrm{C} て ゙ 4 \%\right)$ という結論を得た(図 2 (B)) .

温度制御デバイスをさらに小型化すれば，更に早い応答 速度が期待できる. シリコン基板上にクロム $(\mathrm{Cr})$ と白金 $(\mathrm{Pt})$ を 用いてヒータ, 熱電対を $20 \mu \mathrm{m}$ 四方に集積した温度制御デバ イスを製作し，応答速度 $1 \mathrm{~ms}$ を実現した (Gillot et al. 2010). 前述のフェムトリットルチャンバアレイに緑色蛍光蛋白質 (GFP) を格納し， $1 \mathrm{~ms}$ の応答速度で温度を室温から $100^{\circ} \mathrm{C}$ 付近まで 上げるといら実験が実現し，GFP蛍光輝度退色現象をミリ秒ス ケールで計測することもできた，結果，ミ秒スケールにおい て GFP 蛍光輝度は二次の指数関数で退色することが観察され た (Arata et al. 2008b).

これらのマイクロ温度制御デバイスは, その他の蛋白質や核 酸 (Lam et al. 2008, Arata et al. 2009a) の分子レベルでの実時 間計測だけでなく, 熱応答性超分子ヒドロゲルの相転移実験 (Yamaguchi et al. 2008) など, 多様な顕微鏡下温度制御実験 に応用されている. これらの温度制御デバイスがもつ応答速 度である 1 秒から 1 ミ秒の時間スケールでは，核酸のハイブリ ダイゼーションや蛋白質フォールディングなど，主に分子レベ ルでの生命機能が発現する. そのため, マイクロ温度制御デ バイスにより, 分子生物学にとって極めて興味深い時間スケー ルでの熱依存パラメタをリアルタイムでプローブすることが可能 となった.

\section{層流を用いたArabidopsis thalianaの根への局所的化学刺激}

植物の根は，様々な発達段階において，外的環境に対し， 高い可塑性を示す (Walter et al. 2009). In vitro 実験で，根の 周辺の化学環境を局所的に, 高時間分解能で制御できれば, 栄養素や除草剂などの局所的環境刺激に対する応答の計測と, その過程での細胞間シグナリング機能に関する知見が期待で きる. これらの計測を目指して行われてきた従来の実験では, 任意の化学環境に調節したアガロース上で根を成長させ, 根 周辺の化学環境を変化させる手法が用いられていた. しかし, この従来型実験ではミリメートル程度の位置精度しか得られず, 更に化学物質の濃度勾配を一定時間維持することが困難であっ た (Zhang and Forde 1998, Svistoonoff et al. 2007). これらの 問題を克服するため，層流を利用してArabidopsis thalianaの
根周辺の化学環境を局所的にオンチップ制御するマイクロ流 体システムが製作された (図3A: Meier et al.2010).

根周辺の流体解析を行い, チャネル内流速によるせん断力 は 10 dyne $/ \mathrm{cm}^{2}$ 程度であり, 根の成長を妨げないことも確認し た。このマイクロ流体システムでは，刺激物を10-800 $\mu \mathrm{m}$ の位 置分解能で根の局部に与えることができる (図 $3 \mathrm{~B}$ ). 合成オー キシンである 2,4-D (2,4-dichlorophenoxyacetic acid) とその阻 害剤NPA（N-1-naphthylphthalamic acid）を根の任意の部位に 与えることにより，このシステムの有用性が示された。 オーキ シンに応答するDR5プロモーターの下流にGFPをつないだ $D R 5:: G F P$ 遺伝子を導入した Arabidopsis thaliana 形質転換体 を用いた実験により，局所的刺激に対する応答が確認された。 つまり，GFP発現領域は2,4-Dを含む流体にさらされた局所領

(A)
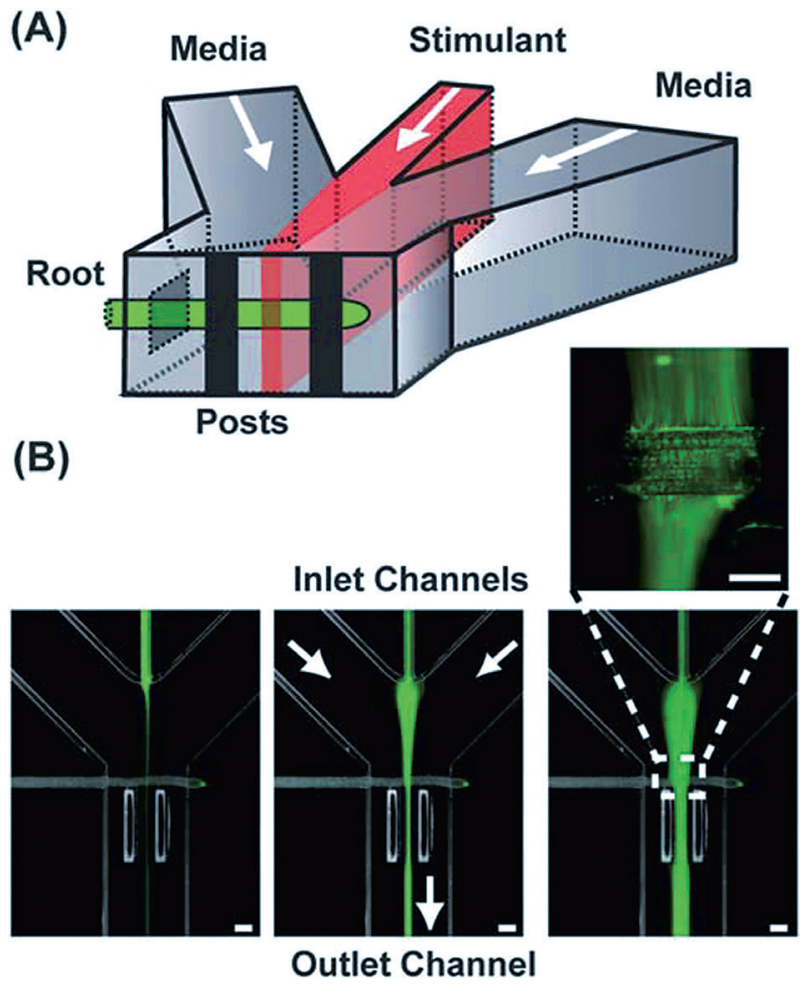

図3 マイクロ流体デバイス内で生きたArabidopsis thalianaの根の周り に形成された層流. (A) 局所的化学刺激実験用マイクロ流体システ ムの概要図. (B) 蛍光マイクロビーズを流してマイクロ流路内の多層 流とその幅を可視化した. スケールバーは200 $\mu \mathrm{m}$. Meier et al. 2010, reproduced by permission of The Royal Society of Chemistry. 


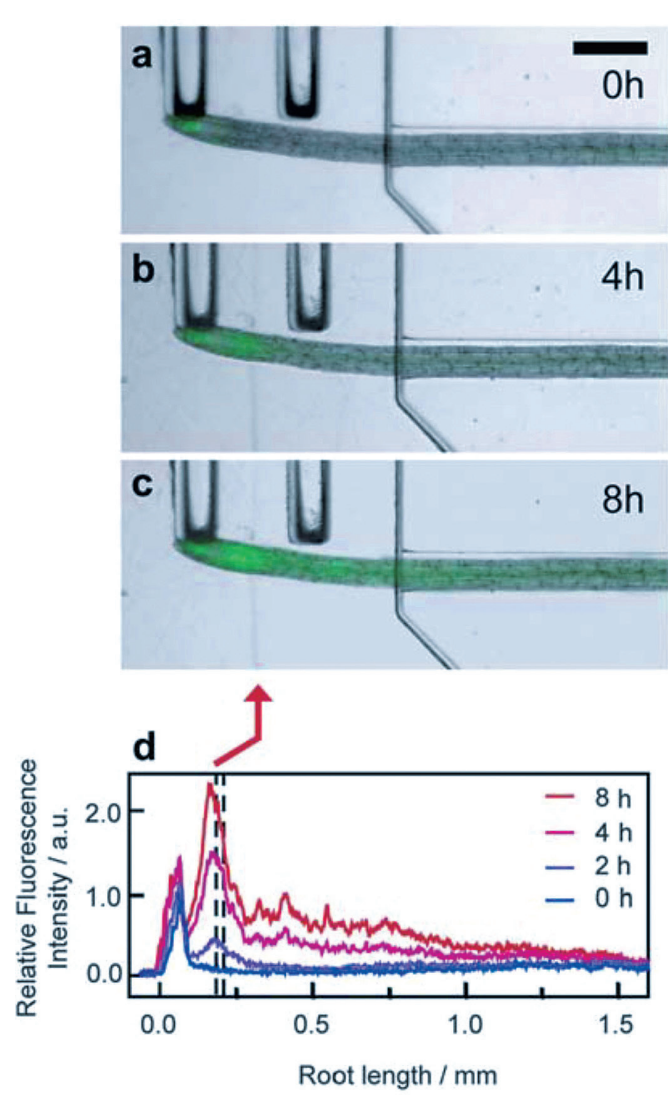

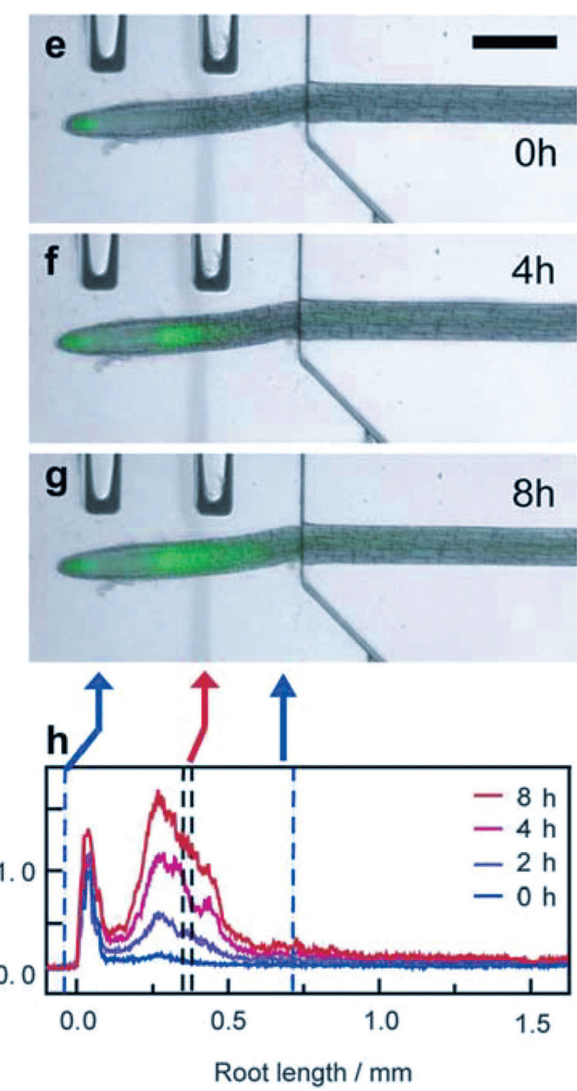

図4 (a-c) と (e-g) 多層流を用い たArabidopsis thalianaの根の局 所刺激. 明視野画像之化学刺激 後の DR5::GFP遺伝子を導入し たArabidopsis thaliana 形質転換 体の蛍光画像を重叔合わせてあ る. (d とh) 合成オーキシンであ る2,4-Dとその阻害剤である2,4-D/ NPA による刺激実験でGFP蛍光 輝度分布に変化が見られた。黒 と青の点線は, それぞれ2,4-D とNPAを与えた領域を示す。赤 い矢印が 2,4-D刺激を, 青い矢 印がNPA刺激を示す。スケール バーは $250 \mu \mathrm{m}$. Meier et al. 2010, reproduced by permission of The Royal Society of Chemistry.
域と一致した (図4).2,4-Dを含む流れの両隣に, オーキシン 伝達阻害剂であるNPAを含む流れを形成したところ，NPAが オーキシンの細胞間伝達を阻害するため, オーキシン伝達に 差が見られた. 更に, 2,4-Dによる $10 \mu \mathrm{m}$ 程度の局所的刺激が, 根の表面における根毛の成長などの形態変化を促進すること も確認された，これらの結果は，従来のアガロースゲルを用い た実験による先行研究と整合するものである. このマイクロ流 体システム用いる実験手法は, 窒素, リン酸塩, 塩および植 物性ホルモンを含む, 任意の化学物質に対する根の応答を観 察するための汎用性の高い手法であるといえる.

\section{花粉管ガイダンスの定量的解析を目指すマイクロ流路システム}

これまで植物生殖に関わる様々な因子が単離され, 理解が 深まっている一方 (Okuda et al. 2009), 花粉管と雌しべ間の情 報伝達メカニズムに関しては多くの謎が残されている．従来の アガロースゲル培地上のアッセイ系では無数の花粉管細胞が 無秩序に伸長するため, 花粉管挙動の定量的解析が困難で あることが研究進展を妨げる大きな要因の一つであった． 微細 加工技術では, これらの組織や細胞と同じスケールの構造体 が製作可能であり, 多数のプロセスを一度の実験で高感度か つ定量的に行うマイクロデバイスの製作が可能である. 我々は, マイクロ流路デバイスを用いて個々の花粉管とシグナリング分 子の相互作用を定量的に解析するための基盤技術確立を目 指している. 本研究では, 個々の花粉管細胞を配向し, その 配置, 向きの制御により安定した観察と, シグナリング分子と の相互作用の定量的解析を実現するマイクロ流路デバイスを 製作した (Horade et al. 2012).

製作したマイクロ流路デバイスは，受粉した花柱から伸びた
(A)

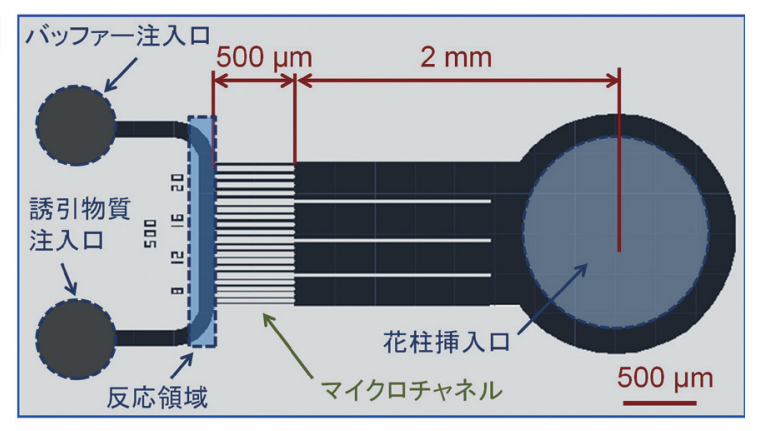

(B)

(C)
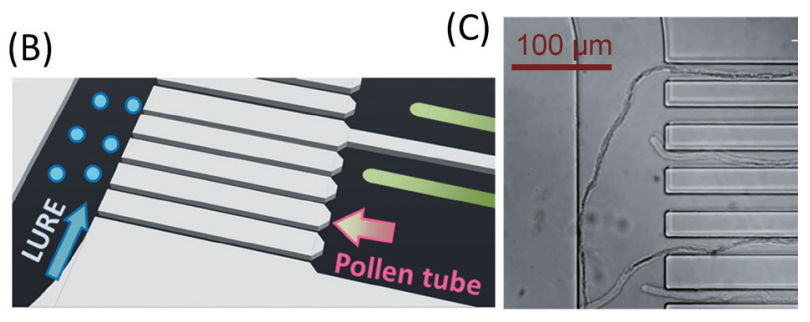

(D)

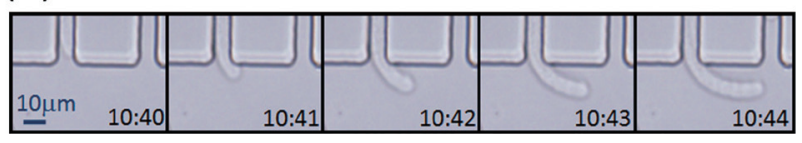

図 5 (A)マイクロ流路デバイス概要図。(B) デバイス内花粉管伸長実験 の模式図. (C) マイクロ流路内で伸長し, 反応領域にさしかかる花粉 管の顕微鏡画像. (D) LURE濃度の高いチャネル右側に向かって伸 びる花粉管. 各コマ右下は受粉後からの経過時間. Horade et al. Proc. MicroTAS 2012から改変して転用. Copyright 2012, The Chemical and Biological Microsystems Society (CBMS). 
複数の花粉管を個別配向するためのマイクロ流路，および誘 引物質との反応領域を備えている. 長さ500 $\mu \mathrm{m}$, 高さ $10 \mu \mathrm{m}$ で，幅は $8 ， 12 ， 16 ， 20 \mu \mathrm{m}$ のPDS 流路をそれぞれ 5 本ず つ設置した構造である(図5(A))，PDMS は空気をため込む 性質があるため, あらかじめ脱気した直後に緩衝液や液体試 料を挿入すれば，流路内の空気がPDMS 外壁に吸収される ため，自動的に流路内に試料を充填させることができ，かつ 気泡が残る問題も回避することができる (Arata et al. 2012)。花 粉管伸長実験においては, 流路内に液体培地を充填した後, 受粉させたTorenia fournieriの花柱を $2 \mathrm{~cm}$ 程度の長さに切り, 花柱差込口に設置した. 受粉後約 10 時間で，伸長した花粉 管は花柱および流路を通過し, 誘引物質反応領域に到達す る (図 $5(\mathrm{~B}, \mathrm{C}))$. 花柱を差込口に設置してから約 6 時間後に 誘引物質流入口に花粉管誘引物質であるLUREを濃度 $1 \mathrm{nM}$ で添加し, 花粉管の伸長方向を観察した. その結果, 流路を 通過した花粉管が，LURE濃度の高い方向に優位差をもって 誘引される現象を確認した (図 5 (D)) . シグナリング分子と細 胞の相互作用解析は, 細胞間コミュニケーションを理解する上 で不可避な課題である. 花粉管とその誘引物質との相互作用 をモデルとした本研究の更なる進展により, 個々の細胞と全体 を調和するホロニックコミュニケーションに関わる重要な知見を 得ることが期待される.

\section{結語}

マイクロデバイスを用いた酵素やモータ蛋白質の生体分子 分析研究, 植物の根や花粉管細胞を対象とした最新の研究 成果を紹介した，従来のバルク計測システムに比べ，マイク ロデバイスを用いることにより，実験の高感度化，高速化，並 列処理などを実現し，かつ少量の試料での実験を，大がかり な設備なしに遂行できるなど，実用的なメリットも享受できる. MEMS に代表される微細加工技術では, サブミリメートルから, サブマイクロメートルスケールの構造物が製作可能であり, 組織, 細胞，生体分子，それぞれの階層における生体試料と同じスケー ルで実験システムを設計，製作できるため，多様な植物試料 を扱う実験への幅広い応用が可能である一方, マイクロ工学 を専門とするグループと植物試料を扱う生物系研究者との密な 連携が必要不可欠である.

PDMS やガラス基板に微細加工を施したマイクロチップを 用いた実験系は，生物物理の分野で主に威力を発揮してき た光ピンセット (Ashikin et al. 1986, MacDonald et al. 2002), 磁気ピンセット (Strick et al. 1996, Arata et al. 2009b), FRET (Fluorescence Resonance Energy Transfer) を含む一分子蛍光 イメージング (Perkins et al. 1994, Roy et al. 2008) など，ナ， メートルスケールで生体試料を操作・計測する一分子システ ムと相性がよく, 双方を併用することによりさらに精度の高い計 測や新たなパラメタの計測を実現している (Galletto et al. 2006, Brewer and Bianco 2008). 我々ERATO東山ライブホロニクス プロジェクトにおいても，マイクロ流路内で花粉管を二次元空 間に閉じ込め，その伸長時の垂直方向の動きを制限すること により，蛍光修飾を施したLUREペプチドと花粉管の相互作 用一分子観察を目指した研究を行っている. このように, これ までマイクロ工学の生体試料応用といえば, 核酸や蛋白質な どの分子への応用ばかりが注目されており，より小さな世界を 扱う一分子計測技術や, ナノ材料との融合が注目されてきた。 しかし, 植物生理学, 植物形態学への応用を目指した場合,
興味深い階層は組織(ミリメートルスケール)から細胞(マイクロメー トルスケール)であることも多い. それに伴い, 扱う試料のスケー ルも幅が大きく, これまでのトレンドから視点を変え, マイクロ より大きなミリの技術へも目を向けることが重要な方向性の一つ であると考えらえる. 古典的な精密加工技術だけでなく, 近年 複雑な構造物の高アスペクト比製作が可能となった光造形技 術 (Varadan et al. 2001) などを積極的に活用することにより， ス マートで実用的な “Plant/Machine Interface (PMI)”が期待でき る. マイクロスケールのプラットフォームを基盤に，ナノとミリ双 方のスケールそれぞれにおいて威力を発揮する技術とマイクロ 工学との融合が, 今後の重要な課題の一つとなるであろう.

\section{引用文献}

Arata, H. F., Rondelez, Y., Noji, H., and Fujita, H. (2005) Temperature alternation by an on-chip microheater to reveal enzymatic activity of beta-galactosidase at high temperatures. Anal Chem 77: 4810-4814.

Arata, H. F., Noji, H., and Fujita, H. (2006) Motion control of single $\mathrm{F}_{1}$-ATPase rotary biomolecular motor using microfabricated local heating devices. Applied Physics Letters 88: 083902.

Arata, H. F., Kumemura, M., Sakaki, N., and Fujita, H. (2008a) Towards single biomolecule handling and characterization by MEMS. Anal Bioanal Chem 391: 2385-2393.

Arata, H. F., Gillot, F., Nojima, T., Fujii, T., and Fujita, H. (2008b) Millisecond denaturation dynamics of fluorescent proteins revealed by femtoliter container on micro-thermodevice. Lab on a Chip 8: 1436-1440.

Arata, H. F., and Fujita, H. (2009) Miniaturized thermocontrol devices enable analysis of biomolecular behavior on their timescales, second to millisecond. Integr Biol 1: 363-370.

Arata, H. F., Gillot, F., Collard, D., and Fujita, H. (2009a) Millisecond analysis of double stranded DNA with fluorescent intercalator by micro-thermocontrol-device. Talanta 79: 963-966.

Arata H., Dupont, A., Miné, J., Disseau, L., Renodon-Cornière, A., Takahashi, M., Viovy, JL., and Cappello, G. (2009b) Direct observation of twisting steps during Rad51 polymerization on DNA. Proc Natl Acad Sci USA 106: 19239-19244.

Arata, H., Komatsu, H., Hosokawa, K., and Maeda, M. (2012) SubAttomole MicroRNA Detection with Laminar Flow-Assisted Dendritic Amplification on Power-Free Microfluidic Chip. PLoS One 7: e48329.

Ashkin, A., Dziedzic, J. M., Bjorkholm, J. E., and Chu, S. (1986) Observation of a single-beam gradient force optical trap for dielectric particles. Optics Letters 11: 288-290.

Auroux, P. A., Iossifidis, D., Reyes, D. R., and Manz, A. (2002) Micro total analysis systems. 2. Analytical standard operations and applications. Anal Chem 74: 2637-52.

Craighead, H. (2006) Future lab-on-a-chip technologies for interrogating individual molecules. Nature 442: 387-393.

Brewer, L. R., and Bianco, P. R. (2008) Laminar flow cells for singlemolecule studies of DNA-protein interactions. Nature Methods 5: 517-525.

Galletto, R., Amitani, I., Baskin, R. J., and Kowalczykowski, S. C. (2006) Direct observation of individual RecA filaments assembling on single DNA molecules. Nature 443: 875-878.

Gillot, F., Arata. H. F., Morin, F. O., and Fujita, H. (2010) Manufacturing process and thermal characterization of a fast temperature switching microdevice for real-time biological experiments. Microsyst Technol 16: $1821-1824$.

Horade, M., Mizuta, Y., Kaji, N., Higashiyama, T., and Arata, H. (2012) Plant-on-a-Chip Microfluidic-System for Quantitative Analysis of Pollen Tube Guidance by Signaling Molecule: Towards Cell-to-Cell Communication Study. Proceedings of MicroTAS 2012, 1027-1029.

Judy, J. W. (2001) Microelectromechanical systems (MEMS): fabrication, design and applications. Smart Mater Struct 10: 11151134. 
Kitamura, K., Tokunaga, M., Iwane, A. H., and Yanagida, T. (1999) A single myosin head moves along an actin filament with regular steps of 5.3 nanometres. Nature 397: 129-134.

Kurihara, D., Hamamura, Y., and Higashiyama, T. (2013) Livecell analysis of plant reproduction: Live-cell imaging, optical manipulation, and advanced microscopy technologies. Dev Growth Differ, in press.

Lam, L., Sakakihara, S., Ishizuka, K., Takeuchi, S., Arata, H. F., Fujita, H., and Noji, H. (2008) Loop-mediated isothermal amplification of a single DNA molecule in polyacrylamide gel-based microchamber. Biomed Microdevices 10: 539-546.

Luo, W., He, K., Xia, T., and Fang, X. (2013) Single-molecule monitoring in living cells by use of fluorescence microscopy. Anal Bioanal Chem 405: 43-49.

MacDonald, M. P., Paterson, L., Volke-Sepulveda, K., Arlt, J., Sibbett, W., and Dholakia, K. (2002) Creation and Manipulation of ThreeDimensional Optically Trapped Structures. Science 296: 1101-1103.

McDonald, J. C., Duffy, D. C., Anderson, J. R., Chiu, D. T., Wu, H., Schueller, O. J., and Whitesides, G. M. (2000) Fabrication of microfluidic systems in poly(dimethylsiloxane). Electrophoresis 21: 27-40.

McDonald, J. C., and Whitesides, G. M. (2002) Poly(dimethylsiloxane) as a material for fabricating microfluidic devices. Acc Chem Res 35: 491-499.

Meier, M., Lucchetta, E. M., and Ismagilov, R. F. (2010) Chemical stimulation of the Arabidopsis thaliana root using multi-laminar flow on a microfluidic chip. Lab on a chip 10: 2147-2153.

Noji, H., Yasuda, R., Yoshida, M., and Kinosita, Jr. K. (1997) Direct observation of the rotation of $\mathrm{F}_{1}$-ATPase. Nature 386: 299-302.

Okuda, S., Tsutsui, H., Shiina, K., Sprunck, S., Takeuchi, H., Yui, R., Kasahara, R. D., Hamamura, Y., Mizukami, A., Susaki, D., Kawano, N., Sakakibara, T., Namiki, S., Itoh, K., Otsuka, K., Matsuzaki, M., Nozaki, H., Kuroiwa, T., Nakano, A., Kanaoka, M. M., Dresselhaus, T., Sasaki, N., and Higashiyama, T. (2009) Defensinlike polypeptide LUREs are pollen tube attractants secreted from synergid cells. Nature 458: 357-361.

Perkins, T. T., Quake, S. R., Smith, D. E., Chu, S. (1994) Relaxation of a single DNA molecule observed by optical microscopy. Science 264: 822-826.

Reyes, D. R., Iossifidis, D., Auroux, P. A., and Manz, A. (2002) Micro total analysis systems. 1. Introduction, theory, and technology. Anal Chem 74: 2623-2636.

Rondelez, Y., Tresset, G., Tabata, K. V., Arata, H., Fujita, H., Takeuchi, S., and Noji, H. (2005) Microfabricated arrays of femtoliter chambers allow single molecule enzymology. Nat Biotechnol 23: 361-365.

Roy, R., Hohng, S., and Ha, T. (2008) A practical guide to singlemolecule FRET. Nat Methods 5: 507-516.

Strick, T. R., Allemand, J-F., Bensimon, D., Bensimon, A., Croquette, V. (1996) The Elasticity of a Single Supercoiled DNA Molecule. Science 271: 1835-1837.

Svistoonoff, S., Creff, A., Reymond, M., Sigoillot-Claude, C., Ricaud, L., Blanchet, A., Nussaume, L., and Desnos, T. (2007) Root tip contact with low-phosphate media reprograms plant root architecture. Nat Genet 39: 792-796.

Trimmer W. S. (1997) Micromechanics and MEMS-Classic and Seminal Papers to 1990. IEEE Press, Piscataway, NJ.

Varadan, V. K., Jiang, Z., and Varadan, V. V. (2001) Microstereolithography and other fabrication techniques for 3D MEMS. John Wiley \& Sons, LTD, Chichester.

Walter, A., Silk, W. K., and Schurr, U. (2009) Environmental effects on spatial and temporal patterns of leaf and root growth. Annu Rev Plant Biol 60: 279-304.

Whitesides, G. M. (2006) The origins and the future of microfluidics. Nature 442: 368-373.

Yamaguchi, S., Matsumoto, S., Ishizuka, K., Iko, Y., Tabata, K. V., Arata, H. F., Fujita, H., Noji, H., and Hamachi, I. (2008) Thermally responsive supramolecular nanomeshes for on/off switching of the rotary motion of $\mathrm{F}_{1}$-ATPase at the single-molecule level. Chem Eur J 14:1891-1896.

Zhang, H., and Forde, B. G. (1998) An Arabidopsis MADS box gene that controls nutrient-induced changes in root architecture. Science 279: 407-409.

Received: 31 January 2013 